\title{
Perancangan Mesin Tetas Telur Otomatis Menggunakan Sensor Suhu dan Sensor Udara
}

\author{
Alex Surapati ${ }^{1 *}$, Reza Satria Rinaldi ${ }^{1}$, Okta Wahyudi ${ }^{1}$ \\ ${ }^{1}$ Program Studi Teknik Elektro Fakultas Teknik Universitas Bengkulu \\ *E-mail: alexsurapati@unib.ac.id
}

\begin{abstract}
The design of quail egg incubators is intended to facilitate the hatching process. The heat source used in the incubator is produced from heaters that use incandescent lamps and humidifiers are used as humidity regulators. The temperature regulator uses a fan to maintain air circulation and reduce the temperature when the temperature has exceeded the setpoint. This tool is equipped with a DHT11 temperature and humidity sensor, an incubator motor is used for the egg turning process, a sound sensor is used to detect if an egg has hatched and a GSM module will send an SMS notification to the farmer. The whole system is controlled by Arduino Mega 2560. During the hatching period, the temperature needed to incubate quail eggs is $390 \mathrm{C}$ and humidity is $60 \%$. The eggs in the hatching machine are rotated once every 3 hours with a 45o rotation angle. This is so that the egg can be heated evenly. The hatching process takes 18 days, with a hatching success rate of $98 \%$ of 50 eggs. The use of power in the hatching machine is on average 62.44 watts up to 83.45 watts and for 1 hatching period for 18 days, that is $25.2392 \mathrm{kWh}$.

Keywords: Arduino Mega 2560, DHT11, humidifier, GSM module
\end{abstract}

\section{ABSTRAK}

Perancangan mesin penetas telur puyuh dimaksudkan untuk memudahkan proses penetasan. Sumber panas yang diguanakan pada mesin penetas ini dihasilkan dari pemanas yang menggunakan lampu pijar dan humidifier digunakan sebagai pengatur kelembaban. Pengatur suhu menggunakan kipas untuk menjaga sirkulasi udara dan menurunkan suhu bila suhu telah melebihi setpoint. Alat ini dilengkapi dengan sensor suhu dan kelembaban DHT11, motor inkubator digunakan untuk proses pemutaran telur, sensor suara digunakan untuk mendeteksi apabila telur ada yang menetas dan modul GSM akn mengirim SMS pemberitahuan ke peternak. Keseluruhan sistem dikontrol dengan Arduino Mega 2560. Selama periode penetasan, suhu yang diperlukan untuk menetaskan telur puyuh sebesar $39^{\circ} \mathrm{C}$ dan kelembaban sebesar
$60 \%$. Telur yang ada di dalam mesin tetas diputar setiap 3 jam sekali dengan sudut putaran $45^{\circ}$. Hal ini dimaksudkan agar pemanasan telur dapat merata. Proses penetasan selama 18 hari, dengan tingkat keberhasilan penetasan sebesar $98 \%$ dari 50 butir telur. Penggunaan daya pada mesin tetas ini rata-rata 62,44 watt sampai dengan 83,45 watt dan untuk 1 periode penetasan selama 18 hari yaitu $25,2392 \mathrm{kWh}$.

Kata kunci: Arduino Mega 2560, DHT11, humidifier, modul GSM

\section{PENDAHULUAN}

Krisis ekonomi mengakibatkan bertambahnya pengangguran. Lahan pekerjaan semakin berkurang sehingga dibutuhkan kemampuan untuk menemukan lahan usaha baru, salah satunya dengan beternak burung puyuh. Kemampuan tumbuh dan berkembang biak puyuh sangat cepat, dalam waktu 41 hari puyuh mampu berproduksi dan dalam satu tahun dapat menghasilkan tigas sampai empat keturunan [1].

Permasalahan penelitian ini adalah bagaimana merancang alat penetas telur otomatis sehingga dapat menetaskan telur dalam jumlah banyak dan pada waktu bersamaan. Penggunaan mesin tetas telur puyuh manual membutuhkan tenaga kerja yang harus mengawasi mesin guna mengontrol suhu dan pembalikan telur. Pembalikan telur dilakukan secara rutin yaitu minimal 2 kali pembalikan setiap harinya. Suhu dalam mesin tetas harus selalu terjaga apabila suhu berada di bawah ambang batas, maka kuning telur tidak terserap secara maksimal oleh embrio dan akan menyebabkan penyakit yolk saculitis. Sebaliknya, bila suhu melebihi ambang batas, maka telur akan cepat menetas sehingga pusar tidak menutup sempurna [1].

Mesin tetas telur yang ada di pasaran bertipe EM1000AT menggunakan pengoperasian otomastis dengan memutar rak sendiri dengan kapasitas kurang lebih 1000 butir telur. Mesin jenis ini mempunyai panjang $90 \mathrm{~cm}$, lebar $60 \mathrm{~cm}$ dan tinggi $125 \mathrm{~cm}$, memerlukan asupan listrik 250 watt dan sumber tegangan 220 volt. Bahan yang digunakan berupa multipleks maupun medium density fiberboard (MDF). 
Pada alat yang dirancang, daya mesin sebesar 62 83 watt lebih kecil dibandingkan dengan daya mesin yang ada di pasaran yaitu sebesar 250 watt. Tingkat keberhasilan pada alat yang dirancang adalah $98 \%$, sedangkan pada alat yang di pasaran $95 \%$.

Tujuan penelitian ini adalah merancang alat penetas telur puyuh otomatis menggunakan sensor suhu dan kelembaban DHT11. Pemutar rak telur menggunakan motor inkubator. Sumber panas menggunakan lampu pijar dan pengaturan kelembaban dalam menggunakan humidifier. Tampilan paramater suhu dan kelembaban dalam ruang penetasan digunakan LCD 16x2. Penggunaan LCD memudahkan pemantauan keadaan suhu dan kelebaban mesin. Sensor suara akan digunakan sebagai pendeteksi suara bila telur sudah menetas, dan akan memberitahukan ke peternak melalui sms dengan menggunkan modul gsm.

Manfaat alat tetas otomatis ini diantaranya adalah tingkat keberhasilan penetasan sebesar 98\%, pemantauan suhu dan kelembaban mesin lebih mudah, telur yang sudah menetas lebih terpantau karena sensor suara akan terhubung ke peternak melalui modul gsm sehingga memudahkan, serta alat tetas ini harganya lebih terjangkau.

\section{TINJAUAN PUSTAKA}

Burung puyuh Japonica (Coturnix coturnix japonica) tidak dapat mengerami telurnya sendiri sehingga penetasan telur harus dibantu dengan mesin tetas.Ciri-ciri fisik yang dijadikan pedoman dalam memilih telur yang baik untuk bibit diantaranya bukan berasal dari perkawinan saudara [1]. Telur sebaiknya diambil dari induk betina berumur 4-10 bulan dan dipelihara bersama pejantan dengan perbandingan 2$3: 1$. Telur tersebut tidak boleh berumur lebih dari 5 hari karena daya tetasnya akan menurun. Setelah 5 hari penyimpanan, saya tetas telur menurun sebesar $3 \%$ per hari [1].

Prinsip dasar kerja mesin tetas sangat sederhana terdiri atas kotak tahan panas yang ter dapat alat pelembab udara berupa baskom yang berisi air serta alat pe Untukngukur suhu. Kestabilan suhu $\left(39^{\circ} \mathrm{C}\right)$, su mber panas konstan, normal, dan menjangkau radius panas yang dibutuhkan telur serta kelembaban harus mencukupi dan ventilasinya memadai.Jarak antara tempat telur dan pemanas $\pm 10 \mathrm{~cm}$ dan antara telur dengan bak air sekitar $10 \mathrm{~cm}$ [1]. Posisi telur sebaiknya $45^{\circ}$ dengan bagian tumpul (bagian berongga udara) terletak di atas.

Penetasan biasanya terjadi pada hari ke 17-19 dengan proses penetasan selama 3 jam. Telur yang $t$ idak menetas selama 3 jam dapat disingkirkan karena bila dipaksakan menetas maka kualitas bibitny rendah dan mudah mati. Tingkat keberhasilan pada penetasan tersebut adalah $70 \%$ anak puyuh dan peling sedikit $60 \%$ diantaranya adalah betina [1].

Dari semua tahap-tahap penetasan telur ada 5 poin utama yang harus diperhatikan pada incubator mesin penetas telur [2], yaitu :

1. Suhu (Temperatur)

2. Kelembaban Udara (Humidity)

3. Ventilasi (Ventilation)

4. Pemutaran Telur (Egg Turning)

5. Kebersihan (Cleanliness).

Perancangan mesin tetas telur terdiri atas sistem mekanik dan hardware. Sistem mekanik berupa motor inkubator yang berfungsi sebagai penggerak rak telur. Modul motor inkubator terdiri dari modul timer, modul sinkron CW/CCW 220 Vac 4-6 rpm, gir set besar kecil, dan 2 limit switch [3]. Pada saat dihidupkan pertama kali motor akan berputar berlawanan atau searah jarum jam. Rak penetas harus diberi pembatas yang juga berfungsi sebagai dudukan siwitch. Pada saat motor berputar dan menekan switch 1, maka motor akan berhenti sejenak selama 6 detik, kemudian motor akan berputar ke arah yang berlawanan dan menekan switch 2 lalu motor akan diam selama 3 jam/6 jam (yang dapat diatur dengan mengubah posisi switch pada modul timer). Motor akan berputar terus sampai menekan switch 1 (berhenti 3 atau 6 jam) dan seterusnya [2].

Perancangan hardwre meliputi 1 unit kendali Arduino Mega 2560, sensor suhu dan kelembaban DHT11, sensor suara, LCD 16x2, lampu pijar sebagai pemanas, kipas DC sebagai pendingin dan sirkulasi udara, humidifier sebagai pengatur kelembaban dan modul GSM sebagai penanda bahwa telur telah menetas. Arduino Mega 2560 adalah sebuah board mikrokontroler yang didasarkan pada ATMega 16U2 sebagai converter USB ke serialnya. Angka 2560 untuk menandakan keluaran (produk) Arduino. Arduino Mega mempunyai 54 pin digital input/output (15 diantaranya dapat digunakan sebagai output PWM), 16 analog input, 4 UART (hardware port serial), sebuah osilator kristal $16 \mathrm{MHz}$, sebuah koneksi USB, sebuah power jack, ICSP header, dan sebuah tombol reset. Arduino Mega memuat semua yang dibutuhkan untuk menunjang mikrokontroler agar mudah menghubungkannya ke sebuah komputer dengan sebuah kabel USB atau mensuplainya dengan sebuah adaptor AC ke DC, Mega kompatibel dengan kebanyakan perisai yang dirancang untuk Arduino Duemilanove atau Diecimila [4].

Alat pengubah sumber listrik dari AC ke DC adalah penyearah. Alat ini berupa rangkaian elektronik 
dengan komponen utama dioda. Penyearah tegangan bolak balik menggunakan penyearah gelombang penuh dengan menggunakan sebuah dioda jembatan/bridge atau empat buah dioda. Gelombang keluarannya lebih baik bila dibandingkan dengan penyearah setengah gelombang [5]. Penyearah jembatan menghasilkan tegangan $\mathrm{V}_{\mathrm{dc}}$ yang mendekati nilai rms tegangan yang disearahkan, yaitu $90 \%$ dari nilai rms tegangan sisi sekunder transformator. Untuk menghitung tegangan keluaran $\left(\mathrm{V}_{\mathrm{dc}}\right)$ dari rangkaian jembatan penyearah, maka dapat digunakan persamaan (1) dan persamaan (2) berikut.

$$
\mathrm{V}_{2 \mathrm{P}}=1,41 \mathrm{~V}_{2 \mathrm{rms}}
$$

$\mathrm{V}_{\mathrm{dc}}=0,636 \mathrm{~V}_{2 \mathrm{P}}$

$\mathrm{V}_{2 \text { rms }}$ adalah tegangan sekunder yang merupakan keluaran dari trafo, dan $\mathrm{V}_{2 \mathrm{P}}$ adalah tegangan puncak atau nilai puncak dari gelombang sinus [5].

Tegangan keluaran $V_{L}$ yang dihasilkan oleh rangkaian-rangkaian penyearah yang masih belum berupa tegangan DC yang konstan nilainya, tetapi masih berupa tegangan DC yang berdenyut. Bentuk tegangan DC seperti ini hanya dapat digunakan pada pemakaian yang terbatas seperti pengeisian baterai dan menjalankan motor DC. Untuk menghasilkan tegangan DC yang lebih konstan, maka pada rangkaian penyearah perlu ditambahkan suatu penapis, yang umum digunakan adalah komponen kapasitor. Penapis kapasitor ini ditempatkan pada keluaran rangkaian penyearah dengan terhubung paralel terhadap beban. Penurunan tegangan yang kecil dari puncak $\mathrm{V}_{\mathrm{IN}}$ yang pertama menuju ke puncak $\mathrm{V}_{\mathrm{IN}}$ berikutnya disebut tegangan riak (ripple). Untuk menghitung nilai tegangan ripple, maka dapat digunakan persamaan (3) dan (4) berikut.

$$
\begin{aligned}
& V_{\text {rip }}=\frac{V 2 P}{2 \cdot F i n \cdot R L \cdot C} \\
& \mathrm{~V}_{\text {rip }}=\frac{I}{f x C}
\end{aligned}
$$

Untuk menghitung nilai Vdc digunakan persamaan (5).

$$
\mathrm{V}_{\mathrm{dc}}=\mathrm{V}_{2 \mathrm{P}}-\frac{\text { Vrip }}{2}
$$

Dengan:

$\mathrm{V}_{\text {rip }}=$ tegangan ripple (Volt)

$\mathrm{I}=\operatorname{arus}$ (Ampere)

$\mathrm{f}=$ frekuensi $(\mathrm{Hz})$

$\mathrm{C}=$ kapasitansi (Farad)

Pada sistem tenaga listrik, daya merupakan jumlah energi yang digunakan untuk melakukan kerja atau usaha. Untuk menghitung nilai daya listrik digunakan persamaan (6) berikut.

$$
\mathrm{P}=\mathrm{I} \times \mathrm{V}
$$

Dengan $\mathrm{P}$ adalah daya (watt), $\mathrm{V}$ adalah tegangan (Volt) dan I adalah arus (Ampere) [7].
Untuk mengubah energi listrik menjadi energi mekanik dibutuhkan motor sinkron yang mempunyai kumparan jangkar pada stator dan kumparan medan pada rotor. Kumparan jangkarnya berbentuk sama dengan mesin induksi, sedangkan kumparan medan mesin sinkron dapat berbentuk kutub sepatu atau kutub dengan celah udara sama rata (rotor silinder) [8]

Sensor suhu dan kelembaban DHT11 merupakan sensor dengan kalibrasi sinyal digital yang mampu memberikan informasi suhu dan kelembaban. Sensor ini termasuk elemen resistif dan perangkat pengukur suhu NTC, memiliki kualitas yang sangat baik, respon cepat, dan dengan harga yang terjangkau [5].

Konstruksi motor sinkron sama dengan generator sinkron, tetapi berbeda pada keluarannya. Untuk menghitung nilai daya output motor sinkron digunakan persamaan (7) dimana Pout $=p$ (daya output motor sinkron sama dengan nilay daya aktif motor).

$$
\begin{aligned}
& \mathrm{P}=\text { V.I. } \operatorname{Cos} \varphi \\
& \mathrm{I}=\frac{P}{V \cdot \cos \varphi}
\end{aligned}
$$

Setelah nilai arus didapat maka dilakukan perhitungn daya input motor sinkron, dimana nilai Pin $=\mathrm{S}$ (input motor sinkron sama dengan nilai daya semu motor) dengan menggunakan persamaan (9).

$\mathrm{S}=\mathrm{V}$. I

Perhitungan nilai efisiensi $(\eta)$ dari motor sinkron menggunakan persamaan (10).

$$
\eta=\frac{\text { Pout }}{\text { Pin }} \times 100 \%
$$

DHT11 memiliki fitur kalibrasi yang sangat akurat yang disimpan dalam OTP program memory, sehingga ketika internal sensor mendeteksi sesuatu, maka modul ini membaca koefisien sensor tersebut.

Kelembaban sangat dipengaruhi oleh jujlah uap air di udara. Alat untuk menambah jumlah uap air di udara dalam satu ruangan atau aliran udara adalah humidifier. Alat ini bekerja dengan cara menguapkan air pada sebuah tempat penampungan air. Pelembab udara atau air humidifier berfungsi untuk menyemprotkan air ke udara agar dapat mengikat bakteri dan virus serta menyeimbangkan kelembaban pada ruangan yang udaranya kering atau ruangan berAC [9]. Humidifier juga berfungsi menurunkan suhu secara stabil dengan tingkat penurunan $\pm 3-4^{\circ} \mathrm{C}$.

Proses pengubahan sinyal analog menjadi sinyal digital.(ADC) terjadi pada konverter/pengubah yang dikenal dengan analog to digital converter. Proses pengubahan ini dikenal juga dengan nama sistem akusisi data. Terdapat empat macam ADC yang 
Tabel 1. Perintah At Command

\begin{tabular}{cc}
\hline AT Command & Fungsi \\
\hline AT & Mengecek koneksi \\
AT+CMGR & Membaca pesan \\
AT+CMGD & Menghapus pesan \\
AT+CMGS & Mengirim pesan \\
\hline
\end{tabular}

memenuhi standar industri, yaitu integrating, tracking converter, successive approximation dan flash/paralel. Keempat jenis ADC tersebut mewakili beberapa macam pertimbangan diantaranya resolusi, kecepatan konversi dan biaya[10].

Operasi ADC membutuhkan tegangan referensi Vref dan clock Fadc (register ADCSRA). Tegangan referensi eksternal pada pin Aref tidak boleh melebihi AVcc. Tegangan referensi eksternal dapat di-decouple pada pin Aref dengan kapasitor untuk mengurangi derau atau dapat menggunakan tegangan referensi internal sebesar $2.56 \mathrm{~V}$ (pin Aref diberi kapasitor secara eksternal untuk menstabilkan tegangan referensi internal). ADC mengkonversi tegangan input analog menjadi bilangan digital sebesar 10-bit. Gnd (0 Volt) adalah nilai minimum yang mewakili ADC dan nilai maksimum ADC diwakili oleh tegangan pada pin Aref minus 1 LSB. Hasil konversi ADC disimpan dalam register pasangan ADCH:ADCL. Sinyal input ADC tidak boleh melebihi tegangan referensi [10].

SMS merupakan salah satu layanan pesan teks yang dikembangkan dan distandarisasi oleh suatu badan yang bernama ETSI (European Telecomunication Standards Institute) sebagai bagian dari pengembangan GSM Phase 2, yang terdapat pada dokumentasi GSM 03.40 dan GSM 03.38. Fitur SMS ini memungkinkan perangkat stasiun seluler digital (Digital Celluler Terminal, seperti ponsel) untuk dapat mengirim dan menerima pesan-pesan teks dengan panjang sampai dengan 160 karakter melalui jaringan GSM [11].

Di balik tampilan menu Messages pada sebuah telepon seluler sebenarnya adalah AT Command yang bertugas mengirim/menerima data ke dan dari SMS Centre. AT Command tiap-tiap SMS device bisa berbeda-beda, tapi pada dasarnya sama. Perintahperintah AT Command biasanya disediakan oleh vendor alat komunikasi yang kita beli. Jika tidak ada, kita dapat mendownloadnya dari internet[11].

AT Command pertama kali dikembangkan masih bernama Hayes Command Set, sebuah script yang

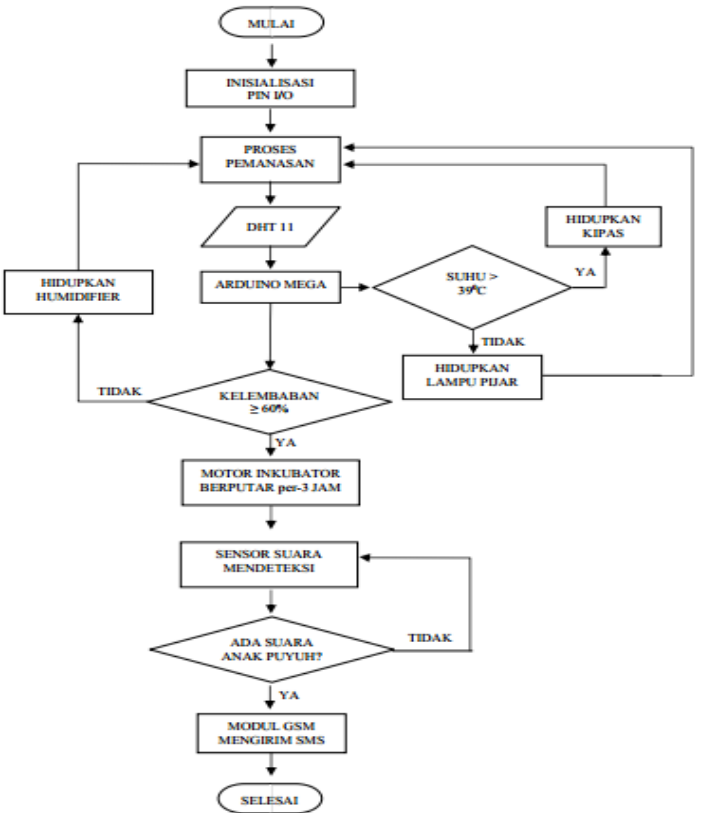

Gambar 1. Diagram Blok

diciptakan untuk dapat menjalankan fungsi dari Modem Hayes berkecepatan 300 baud rate. AT berasal dari kata Attention. Penggunaan AT Command pada handset telah mempermudah untuk mengetahui segala informasi yang terdapat pada handset tersebut. Penggunaan instruksi tertentu dapat mengetahui merk, nomor IME dan lain-lain [8]. Contoh perintah ATCommand yang dapat digunakan dapat dilihat pada Tabel 1.

AT Command juga bisa digunakan untuk mensetting instruksi atau mengaktifkan instruksi pada handset untuk melakukan fungsi tertentu, misalnya melakukan panggilan, mengirim sms, dan lain-lain. Seperti pada pedoman instruksi antarmuka pada modem, instruksi telepon seluler diawali dengan karakter AT dan diakhiri dengan enter atau 0Dh. AT Command untuk SMS, biasanya diikuti oleh data I/O yang diwakili oleh unit-unit PDU. Data yang mengalir ke atau dari SMS Centre harus berbentuk PDU (Protocol Data Unit). PDU berisi bilangan-bilangan heksadesimal yang mencerminkan bahasa $\mathrm{I} / \mathrm{O}[10]$

\section{METODE RISET}

Pada penelitian ini rancangan sistem terbagi menjadi 2 bagian, yang pertama adalah sistem mekanik dan bagian kedua merupakan perancangan hardware. Sistem mekanik berupa motor inkubator yang berfungsi sebagai penggerak rak telur. 


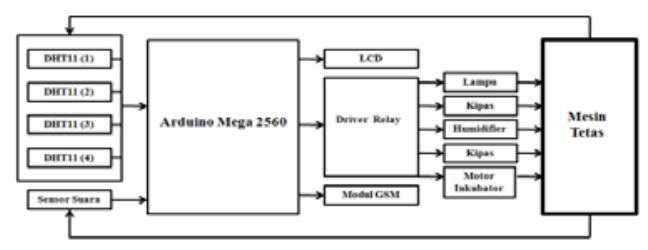

Gambar 2. Diagram Alir Penelitian

Perancangan hardware meliputi 1 unit kendali, sensor suhu dan kelembaban, sensor suara, LCD 16x2, lampu pijar sebagai pemanas, kipas DC sebagai pendingin dan sirkulasi udara, humidifier sebagai pengatur kelembaban, dan modul GSM sebagai penanda bahwa telur sudah menetas. Tahapan akhir adalah perancangan perangkat lunak untuk Arduino Mega 2560 sebagai pengendali sistem. Setelah perangkat jadi, maka dilakukan pengujian sistem secara keseluruhan. Digram alir penelitian ini dapat dilihat pada Gambar 2 berikut.

\section{HASIL DAN PEMBAHASAN}

Pada tahap ini dilakukan pengujian terhadap sistem untuk mengetahui hasil dari perancangan yang telah dibuat. Pengujian sistem ini terdiri dari beberapa tahapan, dimulai dari pengujian terhadap tiap-tiap bagian pendukung sistem hingga pengujian sistem secara keseluruhan.

\section{A. Analisa Rangkaian Power Supply}

Penggunaan nilai kapasitor $\mathrm{C} 1$ pada rangkaian power supply dianalisa menggunakan persamaan (4). Dioda yang digunakan merupakan dioda bridge dengan penapis, maka dengan tegangan sekunder 12 volt dilakukan perhitungan nilai $\mathrm{V}_{2 \mathrm{P}}$ (tegangan puncak) menggunakan persamaan (3) didapat nilai $\mathrm{V} 2 \mathrm{P}=16,92$ Volt.

Nilai Vdc sama dengan nilai output Vout selanjutnya dapat dihitung menggunakan persamaan (5), didapat nilai Vrip $=9,84$ volt $\approx 10$ volt dan hasil perhitungan menggunakan rumus (4) diperoleh besar nilai kapasitor yang dibutuhkan sebesar 2x10-3 Farad $=2000 \mu \mathrm{F}$. Jadi nilai minimal kapasitor yang harus digunakan yaitu sebesar $2000 \mu \mathrm{F}$.

\section{B. Pengujian Power Supply}

Pengujian pertama yang dilakukan adalah pengujian rangkaian penyearah yang berfungsi untuk mengubah tegangan sumber AC menjadi DC. Pengujian dilakukan untuk mengetahui apakah rangkaian tersebut dapat bekerja dengan baik atau tidak dengan cara menghubungkan output dari rangkaian tersebut dengan beban menggunakan resistor $1 \mathrm{~K} \Omega$. Hasil pengukuran menggunakan alat ukur dari pengujian power supply dapat dilihat pada Tabel 2.
Tabel 2. Hasil Pengujian Power Supply

\begin{tabular}{lcccc}
\hline No & $\begin{array}{c}\text { Beban } \mathrm{R}_{\mathrm{L}} \\
(\Omega)\end{array}$ & $\begin{array}{c}\text { Penapis } \mathrm{C} \\
(\mu \mathrm{F})\end{array}$ & $\mathrm{V}_{\mathrm{ac}}(\mathrm{V})$ & $\mathrm{V}_{\mathrm{dc}}(\mathrm{V})$ \\
\hline 1 & 1000 & 4700 & 4,35 & 5,46 \\
2 & 1000 & 4700 & 5,57 & 7,10 \\
3 & 1000 & 4700 & 6,76 & 8,65 \\
4 & 1000 & 4700 & 8,94 & 12,49 \\
5 & 1000 & 4700 & 11,19 & 15,20 \\
\hline
\end{tabular}

Tabel 3. Hasil Perhitungan Dan Perbandingan Tegangan Output ( $\mathrm{V}_{\mathrm{dc}}$ ) Power Supply

\begin{tabular}{ccccc}
\hline $\begin{array}{c}\mathrm{V}_{\mathrm{ac}} \\
\text { (volt) }\end{array}$ & $\begin{array}{c}\mathrm{V}_{\mathrm{dc}} \text { ukur } \\
\text { (volt) }\end{array}$ & $\begin{array}{c}\mathrm{V}_{\mathrm{dc}} \\
\text { hitung } \\
\text { (volt) }\end{array}$ & $\begin{array}{c}\text { Ralat } \\
\text { Mutlak } \\
\text { (volt) }\end{array}$ & $\begin{array}{c}\text { Ralat } \\
\text { Relatif } \\
(\%)\end{array}$ \\
\hline 4,35 & 5,46 & 6,12 & 0,66 & 12,08 \\
5,57 & 7,10 & 7,85 & 0,75 & 10,56 \\
6,76 & 8,65 & 9,52 & 0,87 & 10,06 \\
8,94 & 12,49 & 12,59 & 0,10 & 0,80 \\
11,19 & 15,20 & 15,76 & 0,56 & 3,68 \\
Rata-rata & & & 0,59 & 7 \\
\hline
\end{tabular}

Tegangan sumber $\left(\mathrm{V}_{\mathrm{ac}}\right)$ yang diberikan kepada rangkaian penyearah divariasikan sesuai dengan tegangan sekunder pada trafo. Dari hasil pengukuran beban dan kapasitor pada Tabel 1, maka dapat ditentukan nilai tegangan output rangkaian penyearah menggunakan Persamaan (1), Persamaan (3) dan Persamaan (5), didapat nilai $\mathrm{V}_{2 \mathrm{P}}=6,13$ Volt, nilai $\mathrm{V}_{\text {rip }}$ $=0,01$ Volt dan nilai $\mathrm{V}_{\mathrm{dc}}=6,125$ Volt.

Dengan melakukan cara yang sama diperoleh tegangan output $\left(\mathrm{V}_{\mathrm{dc}}\right)$ dari masing-masing pengujian yang dilihat pada Tabel 3. Jika dilakukan perbandingan antara Vdc hasil pengukuran dengan hasil perhitungan, maka terdpat perbedaan dari kedua nilai tersebut. Untuk menentukan kesalahan atau error dari hasil perbandingan tersebut, maka dilakukan perhitungan kesalahan mutlak dan relatif. Hasil perhitungan didapat nilai ralat mutlak sebesar 0,66 dan ralat relatif sebesar $12,08 \%$.

Power Supply sangat penting dalam memberikan supply energi untuk menghidupkan semua komponen elektronik yang membutuhkan tegangan yang cocok dan stabil. Dari Tabel 3 dapat dilihat persentase kesalahan rata-rata yang diperoleh adalah $7 \%$ dengan kesalahan terbesar $12,08 \%$. Hal ini menunjukkan 


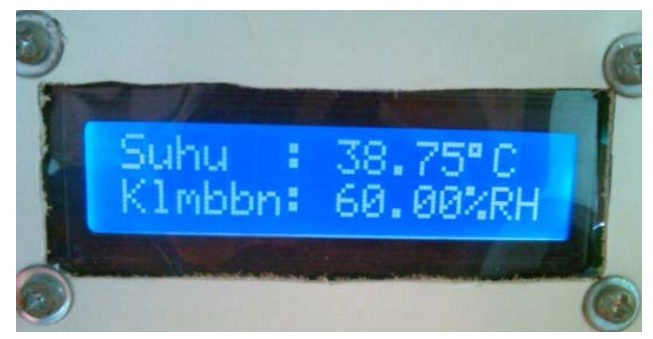

Gambar 3. Tampilan Suhu dan Kelembaban

bahwa power supply dapat bekerja dengan baik. Kesalahan tersebut dapat terjadi dikarenakan kesalahan alat ukur yng kurang akurat, perubahan tegangan sumber dan gangguan pada masing-masing komponen yang digunakan.

Pengujian sistem secara keseluruhan ini dilakukan dengan menggabungkan semua peralatan ke dalam sebuah sistem yang terintegrasi. Tujuannya untuk mengetahui bahwa rangkaian yang dirancang telah bekerja sesuai yang diharapkan. Dari hasil pengujian selama proses dari awal penetasan telur sampai telur menetas ternyata kondisi peralatan masih tetap normal dan tidak terjadi gangguan yang berarti, sehingga mesin tetas telur puyuh otomatis ini sudah dapat beroperasi sesuai harapan.

Arduino Mega 2560 dapat melakukan kontrol pada proses penetasan dimana arduino dapat mengkontrol secara cepat perubahan suhu dan kelembaban yang terjadi pada ruang penetasan. Data suhu dan kelembaban ini diinputkan oleh DHT11 yang bertindak sebagai sensor pada ruang penetasan dan ditampilkan pada layar LCD seperti pada Gambar 3.

Arduino dapat menjalankan proses kontrolnya dengan mengacu pada nilai suhu dan kelembaban yang telah ditentukan (set point). Nilai set point ini digunakan oleh arduino untuk menjalankan sistem kontrol dimana setiap terjadi perubahan nilai suhu, arduino melakukan tugas dengan mengkontrol pengaktifan dan penonaktifkan kipas dan lampu pijar supaya suhu tetap berada pada nilai set point. Sedangkan pada setiap terjadinya perubahan nilai kelembaban arduino akan mengontrol pengaktifan dan penonaktifan humidifier sehingga kelembaban tetap berada pada nilai set point.

\section{Pengujian Motor Inkubator}

Pada pengujian motor inkubator ini, dilakukan untuk mengetahui ketepatan lama waktu pergerakan motor untuk membalik rak telur penetasan dari posisi $45^{\circ}$ ke posisi $-45^{\circ}$.

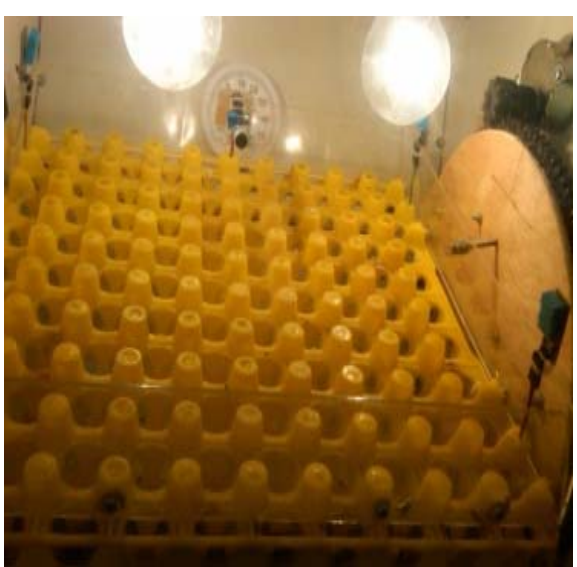

Gambar 4. Rak Telur Penetas Posisi 45

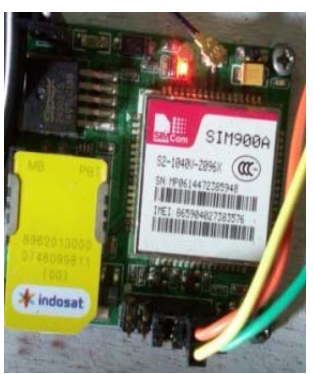

(a)Modul GSM

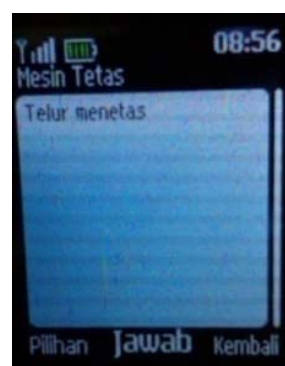

(b)SMS yang diterima
Gambar 5. Hasil Pengiriman SMS

Hasil pengujian tersebut menunjukkan bahwa pergerakan motor dari pertama dihidupkan dari posisi $45^{\circ}$ menuju ke posisi $-45^{\circ}$ membutuhkan waktu yang lebih lama dibandingkan dengan pergerakan motor dari posisi $45^{\circ} \mathrm{ke}-45^{\circ}$ dan sebaliknya. Waktu rata-rata yang dibutuhkan motor untuk berputar dari posisi $45^{\circ}$ ke $-45^{\circ}$ dan sebaliknya adalah 181 menit 12 detik (3 jam, 1 menit, 12 detik).

Motor inkubator mampu bekerja sesuai dengan waktu yang ditentukan. Serta mampu membalik rak telur setiap 3 jam sekali. Motor dapat memutar rak telur secara otomatis setiap tiga jam tanpa ada telur yang jatuh.

Untuk mendeteksi telur yang telah menetas maka digunakan sensor suara. Sensor suara dapat bekerja bekerja dengan baik. Saat ada frekuensi suara yang terdeteksi condenser, maka akan dicocokkan dengan frekuensi suara pada tone decoder, dan jika tone decoder berlogika 1 berarti ada puyuh yang menetas. Sehingga sensor suara memberi input ke arduino dan arduino memproses data sehingga modul GSM dapat mengirimkan SMS ke handphone penerima. Seperti yang dapat dilihat pada Gambar 5 . 

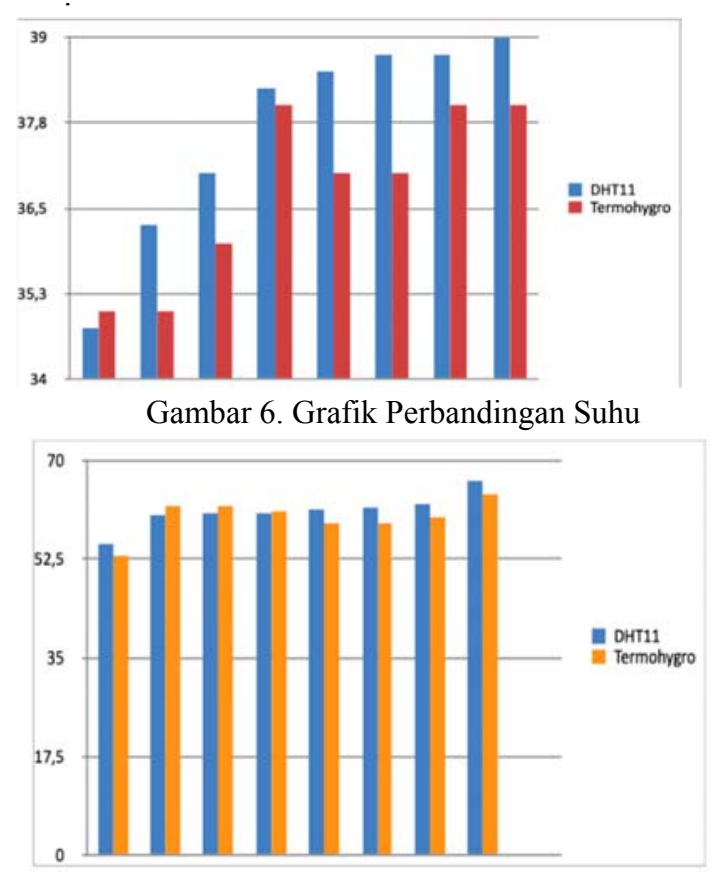

Gambar 7. Grafik Perbandingan Kelembaban

Tabel 4. Data Pengujian Penetasan Tahap I

\begin{tabular}{ccc}
\hline & Normal & 52 \\
Menetas & Cacat & 3 \\
& Mati & 2 \\
\hline \multicolumn{1}{c}{ Tidak Menetas } & 2 \\
\hline Telur berembrio & $\mathbf{5 9}$ \\
Telur tidak berembrio & $\mathbf{1}$ \\
Jumlah Telur & $\mathbf{6 0}$ \\
\hline
\end{tabular}

\section{Pengujian Sensor DHT11}

Pengujian sensor suhu dilakukan dengan membandingkan hasil pengukuran sensor DHT11 dengan thermohygrometer analog. DHT11 memiliki fitur kalibrasi yang sangat akurat

Dari hasil tersebut dapat diambil kesimpulan bahwa kelembaban yang terukur dari DHT11 mendekati kelembaban yang terukur dari termohygro, dengan rata-rata kesalahan $1,85 \%$ dan dengan persentase kesalahan rata-rata adalah 3,11\%. Dari hasil pengujian menunjukkan sensor DHT11 dalam kondisi baik dan layak digunakan.

\section{E. Percobaan 1}

Pengujian mesin tetas telur puyuh otomatis tahap I sebanyak 60 butir telur. Hasil dari pengujian tahap I ini dapat dilihat pada Tabel 4.
Tabel 5. Data Pengujian Penetasan Tahap Ii

\begin{tabular}{lcc}
\hline & Normal & 47 \\
Menetas & Cacat & 2 \\
& Mati & 0 \\
\hline \multicolumn{2}{c}{ Tidak Menetas } & 1 \\
Telur berembrio & $\mathbf{5 0}$ \\
Telur tidak berembrio & $\mathbf{0}$ \\
Jumlah Telur & $\mathbf{5 0}$ \\
\hline
\end{tabular}

Hasil perhitungan persentase fertilitas telur yaitu $98,33 \%$ dari jumlah telur 60 butir. Penetasan terjadi pada hari ke $17-19$, dengan suhu ruang $39^{\circ} \mathrm{C}$ dan kelembaban relatif antara $40-60 \%$. Pembalikan telur dilakukan per 3 jam sekali mulai dari hari ke 1 sampai hari ke 19 dengan sudut kemiringan $45^{\circ}$. Dari pelakuan yang dilakukan didapat persentase daya tetas dari mesin tetas yang dibuat yaitu $96,61 \%$ dan viabilitas daya bertahan hidup anakan puyuh sampai 48 jam yaitu $91,22 \%$ dengan tingkat kematian 3,5\%.

\section{F. Percobaan 2}

Pada pengujian tahap II ini telur puyuh yang diuji coba yaitu sebanyak 50 butir telur. Hasil dari pengujian tahap II ini dapat dilihat pada Tabel 5.

Hasil perhitungan persentase fertilitas telur yaitu $100 \%$ dari jumlah telur 50 butir. Penetasan terjadi pada hari ke $15-19$, dengan suhu ruang $39^{\circ} \mathrm{C}$ dan kelembaban relatif antara $55-60 \%$. Pembalikan telur dilakukan per 3 jam sekali mulai dari hari ke 1 sampai hari ke 19 dengan sudut kemiringan $45^{\circ}$. Dari pelakuan yang dilakukan didapat persentase daya tetas dari mesin tetas yang dibuat yaitu $98 \%$ dan viabilitas daya bertahan hidup anakan puyuh sampai 48 jam yaitu 95,91\% dengan tingkat kematian $0 \%$.

\section{PENUTUP}

\section{A. Kesimpulan}

Kesimpulan yang dapat diambil berdasarkan penelitian yang telah dilakukan adalah sebagai berikut.

1. Sistem mampu menjaga suhu dan kelembaban mesin tetas pada setpoint dengan error rata-rata suhu dan kelembaban yaitu 2,64\% dan 3,11\%.

2. Tingkat keberhasilan penetasan terbesar pada mesin tetas telur puyuh otomatis ini sebesar $98 \%$, pada suhu $39^{\circ} \mathrm{C}$ dan kelembaban relatif $60 \%$.

3. Penggunaan daya pada mesin tetas telur puyuh otomatis ini rata-rata 62,44 watt sampai dengan 83,45 watt. 
4. Penggunaan daya rata-rata pada mesin tetas telur puyuh otomatis ini yaitu $0,0568 \mathrm{kWh}, 1,4022 \mathrm{kWh}$ per hari dan total penggunaan daya untuk 1 periode penetasan selama 18 hari yaitu $25,2392 \mathrm{kWh}$

\section{B. Saran}

Ada beberapa saran yang dapat diberikan setelah melakukan penelitian ini, yaitu sebagai berikut.

1. Untuk penelitian selanjutnya dapat diperbesar kapasitas jumlah telur yang ditetaskan.

2. Sistem pengisian air pada wadah penampung air dapat diotomatiskan, agar kelembaban pada mesin tetas tetap terjaga.

\section{REFERENSI}

[1] Listiyowati, Elly dan Roospitasari, Kinanti. 2007. Puyuh, Tata Laksana Budi Daya Secara Komersial. Jakarta: Penebar Swadaya.

[2] Nurhadi, Imam dan Puspita, Eru. 20 . Rancang Bangun Mesin Penetas Telur Otomatis Berbasis Mikrokontroler ATMEGA8 Menggunakan Sensor SHT 11. Politeknik Elektronika Negeri Surabaya ITS. Surabaya. https://core.ac.uk/download/pdf/123433 51.pdf
[3] User Manual. 2014. "Modul Motor Inkubator" Steigenz

[4] Datasheet. 2014. Arduino Mega 2560. Arduino

[5] Susanto, Heri., Pramana, Rozeff dan Mujahidin. Muhammad. 2013. Perancangan Sistem Telemetri Wireless Untuk Mengukur Suhu Dan Kelembaban Berbasis Arduino Uno R3 Atemega328P Dan Xbee Pro. Tanjung Pinang: Universitas Maritim Raja Ali Haji.

[6] Rinaldi, Reza Satria dan Anggraini, Ika Novia. 2014. Bahan Ajar Elektronika I. Bengkulu: Universitas Bengkulu Fakultas Teknik.

[7] Lister, Eugene C. 1988. Mesin Dan Rangkaian Listrik "Edisi Keenam”. Jakarta: Erlangga.

[8] Chapman, Stephen J. 2001. Electric Machinery and Power System Fundamentals "First Edition”. Australia: McGraw-Hill, Inc.

[9] Winda dan Devin. 2010. Ultrasonic Humidifier. Malang: Mesin Raya

[10] Miranto, Afit. 2014. Perancangan Alat Pemberian Pakan Ayam Kampung Otomatis Berbasis Mikrokontroler Atmega8535. Bengkulu: Program Studi Teknik Elektro, Universitas Bengkulu.

[11] Ciputra, Akhmad. 2011. Perancangan Alat Pencatat KWH Meter dengan Pengiriman Data Menggunakan SMS. Bengkulu: Program Studi Teknik Elektro, Universitas Bengkulu 